Journal of Health Policy and Management (2019), 4(2): 96-104

https://doi.org/10.26911/thejhpm.2019.04.02.04

\title{
Juridical Review of Presumed Consent as the Right of Patients in Emergency Conditions
}

\author{
Rindy Alief Puspitasari'), Isharyanto²), Hari Purwadi²) \\ 1)Masters Program in Law, Universitas Sebelas Maret \\ 2)Faculty of Law, Universitas Sebelas Maret
}

\begin{abstract}
Background: Doctors and patients are two legal subjects who are bound in a therapeutic transaction. This transaction involves informed consent. Informed consent is the doctor's obligation and the patient's rights. There are exceptions to the application of informed consent in emergency situations. The doctor is still obliged to provide help even though the patient is in an unconscious condition and cannot give consent to the action. This is known as the Presumed Consent. This study aimed to explore presumed consent as the right of patients in emergency conditions using juridical review.

Subjects and Method: This was a normative study with a law approach, case study, and conceptual approach. Legal materials used are written documents and the results of interviews. The technique of analyzing legal materials by formulating principles and legal understanding and evaluating the results of interviews. Respondents consisted of 6 General Practitioners who worked in the emergency room, ICU, treatment room, and operating room at PKU Muhammadiyah Sukoharjo Hospital.

Results: According to article 17 of medical ethics code (KODEKI) in 2012, every doctor is obliged to carry out emergency assistance as a form of humanitarian duty. This was similar to Article 51 of Law No. 29 of 2004 concerning Medical Practice. Whereas, in article 29 paragraph (1c) of Law No. 44 of 2009 concerning Hospitals it is explained that the Hospital is also obliged to provide emergency care to patients according to their abilities. If the patient is considered unable to be treated, the doctor must refer to a doctor who is more competent after giving emergency care, but if the doctor has been able to take action according to professional standards and procedures, the doctor must provide an explanation after the patient is aware or to the closest family. The results of interviews with general practitioners at Muhammadiyah Hospital in Sukoharjo, Central Java from 6 respondents all stated that patients had the right to get emergency assistance according to the standard even though without written consent from patients and families. After being aware, the patient and / or family will continue to explain information about the condition and follow-up on its handling.

Conclusion: In accordance with the laws and regulations on informed consent in emergency conditions or called presumed consent, patients are entitled to immediate emergency assistance and the doctor is obliged to carry out help in accordance with professional standards and procedures. The implementation of presumed consent as a patient's right by General Physician of PKU Muhammadiyah Sukoharjo Hospital has been running according to the standard.
\end{abstract}

Keywords: Emergency, Patient Rights, Presumed Consent, Juridical Review.

\section{Correspondence:}

Rindy Alief Puspitasari. Master Program in Law, Universitas Sebelas Maret, Jl. Ir. Sutami 36A, 57126, Surakarta, Central Java. Email : aliefprindy@gmil.com. Mobile: +6285701587295.

\section{BACKGROUND}

Doctors and patients are two related legal subjects in the field of health care. Both of them form medical relations and legal rela- tions. In medical relations, doctors as health care providers while patients as recipients of health services (Ali et al., 2006). Judging from the legal relationship, 
between patients and doctors mutually agree to bind themselves in carrying out treatment for patients, so that an agreement (verbenisenis) is formed. The doctrine of law knows two types of engagement, namely endeavor engagement (inspanning verbintenis) and engagement results (resultaat verbintenis). Engagement between doctors and patients can be classified as endeavor. Doctors are required to make every effort based on knowledge and symptoms to cure patients.

In carrying out their duties, doctors often ask patients to sign a statement stating that medical action to be carried out has been understood and approved by the patient himself and the patient's family. This letter is better known as "Informed Concentration" or "Approval of Medical Measures" (Kusmaryanto, 2016).

Regulations regarding informed consent are listed in Article 45 paragraph (1) to paragraph (6) of Law Number 29 of 2004 concerning Medical Practice (hereinafter referred to as the Medical Practice Law), Regulation of the Minister of Health No. 290 of 2008 concerning Approval of Medical Measures, and Law No. 36 of 2014 concerning Health Personnel (hereinafter referred to as the Law on Health Workers). Article 56 paragraph (1) letter b of the Law on Health Personnel determines that in carrying out the practice, health personnel must obtain approval from the recipient of the health service/family for the action given. Whereas, Article 68 paragraph (1) explains that each individual health service act carried out by health personnel must obtain approval.

Doctors are authorized to seek treatment for their patients' illnesses (Aribowo et al, 2015) and this is part of an agreement in the form of transactions known as therapeutic transactions (Putra, 2001). For the implementation of the Informed Consent, communication is established between doctors and patients is a very important factor. At the ideal level, the communication will encourage a doctor to respect the patient's rights. This is because in principle, the treatment that he will do is not in the doctor's decision but lies in the patient's will (Ayuningtyas and Sondani, 2011).

With complete information from the doctor to the patient or family, the patient will use the right to self-determination and make an informed decision. However, there are a number of conditions in which patients cannot use the right to make decisions. One of the conditions is when the patient is in an unconscious situation and no family member is accompanying him. Unconscious conditions are classified into emergency conditions.

Emergency patients are sufferers who are due to a cause (illness, trauma, accident, anesthetic action) which if not immediately helped will experience a disability, loss of body organs or death (Sudjito, 2003). In this condition, there are exceptions in medical treatment by doctors and achieving patient rights to obtain information (Indonesian Medical Magazine, 2007). The right to information is not obtained by the patient optimally from the doctor who treats it.

Between doctors and patients, each has rights and obligations (Novianto, 2017). In general, rights are a person's demands for something that is his personal needs, in accordance with justice, morality and legality. Regarding the patient's right is always associated with the right to get health care (The right to health care) which is the patient's main right, namely the right to get health care that meets certain criteria so that patients get health efforts, health facilities, and assistance from health workers who fulfill optimal health service standards. 
Based on the descriptions above, in this paper we will discuss the "Juridical Review of Presumed Consent as the Right of Patients in Emergency Conditions."

\section{SUBJECTS AND METHOD}

In this study, the normative juridical method is used to solve legal issues and simultaneously provide prescriptions about what should be needed (Marzuki, 2017). The study approach included:

1. Approach to the Act (statute approach), where the author will carry out activities description, systematization, and interpretation of the law. The positive law used in this approach includes the following laws and regulations:

a. Code of Medical Ethics (KODEKI) in 2012

b. The 1945 Constitution of the Republic of Indonesia;

c. Law Number 29 of 2004 concerning Medical Practice;

d. Law Number 36 of 2009 concerning Health;

e. Law Number 36 of 2014 concerning Health Workers;

f. Law Number 44 of 2009 concerning Hospitals;

g. Minister of Health Regulation Number 290 of 2008 concerning Approval of Medical Measures.

h. Regulation of the Minister of Health Number 47 of 2018 concerning Emergency Services

2. Case studies (case studies), where the author will conduct interviews as a concrete source of research related to the handling of patients in emergency conditions. Respondents consisted of 6 General Practitioners who worked in the emergency room, ICU, treatment room, and operating room at PKU Muhammadiyah Hospital in Sukoharjo; and
3. Conceptual approach, where the author uses literature as a legal material collection technique.

The legal materials used are primary and secondary legal materials. Primary legal material consists of legislation or minutes in making legislation. While the secondary legal material in the form of all publications about the law which are not official documents, including books, texts, dictionaries/legal journals, and the results of interviews.

Legal material collection techniques through library research. The legal material analysis technique used is the deduction method by formulating the principles and legal understanding and evaluating the results of the interview.

$\frac{\text { RESULTS }}{\text { The concept of "agreement" differs slightly }}$ in various cultures and countries (Isharyanto, 2018), for example, according to American law, emphasizes patient autonomy. Elements include competence, disclosure, understanding, volunteerism, and consent (Beauchamp, 2001). Therefore, the emphasis of consent lies in the duty of the doctor to disclose information to the patient. Patients, in this model, are the only people who know the condition and situation in the best way possible, with the doctor as someone who is committed and responsible for providing patient information needs to help patients make optimal decisions.

However, in the UK, it is defined in terms of detailed references to patients and is considered valid when having the following characteristics: patients agree voluntarily, without any coercion. Patients have the capacity and competence to agree (Subramani, 2017). The patient has little information needed to approve the nature of the procedure he will undergo (Ghaderi and 
Malek, 2014). On the other hand, informed consent in Iran is treated as a basic and irreplaceable right of patients.

In Indonesia, the term medical action agreement is used. Legal approval of medical action (medical consent) for doctors is a means of protection to avoid criminal sanctions, and is a patient's right to being recognized by law in the Medical Practice Act. Practically, the approval of medical action can be given by the patient in the following manner:

\section{Implied Constructive Consent}

2. Implied Emergency Consent / Presumed Consent

In this study, we will discuss presumed consent or the approval of medical actions given in an emergency. According to article 17 of KODEKI in 2012, every doctor is obliged to carry out emergency assistance as a form of humanitarian duty. This is similar to Article 51 of the Medical Practice Law. Whereas, in article 29 paragraph (1c) of Law No. 44 of 2009 concerning Hospitals it is explained that the Hospital is also obliged to provide emergency care to patients according to their abilities. If the patient is considered unable to be treated, then the doctor must refer to a doctor who is more competent after giving emergency care, but if the doctor has been able to take action according to professional standards and procedures, the doctor must provide an explanation after the patient is aware or the closest family

The results of interviews conducted by the author at Muhammadiyah Hospital in Sukoharjo, Central Java, with 6 general physicians, were obtained: from 6 respondents all stated that patients were entitled to get emergency assistance according to the standard even without the written consent of patients and families. After being aware, the patient and/or family will continue to explain information about the condi- tion and follow-up on its handling. If there is a patient condition that cannot be handled by the General Physician at the Hospital, then it will be referred to another competent Hospital.

\section{DISCUSSIONS \\ 1. Relationship between doctors and patients in civil law}

The purpose of the patient seeking treatment is to expect healing. According to Machmud (2012), the development of the relationship between doctors and patients can be grouped in the following stages:

a. "Active-passive" relationships, at this stage the patient does not make any contribution to the health services he will receive. He fully gave the doctor to take the necessary actions. At this stage the communication interaction carried out by the patient does not involve the choice of health care measures, because he is unable to provide it. The inability can only be because he really does not have medical knowledge so that he trusts the doctor completely or because his condition does not allow him to give his opinion, for example the patient is unconscious.

b. "Guided cooperation" relationship, the stage of this relationship occurs when the patient is sick but is aware and has the ability to ask for medical help and is willing to cooperate with a doctor. At this stage of the relationship, it appears that there is participation from patients in the health care process. The role of doctors is still more dominant in determining the actions to be taken. Thus the position of the doctor as a person who is trusted by the patient is still significant.

c. "Joint participation" relationship, at this stage of the relationship the patient realizes that he is an equal person with a doctor, and thus if he is in contact with a 
doctor, the relationship is built on a mutually agreed agreement. The agreement was taken after doctors and patients through intensive stages of communication to produce a decision.

Although there were developments in the relationship between doctors and patients, in essence what doctors did was a form of health service. An opinion of Leenen quoted by Wiradharma (1996), stated that the obligation of doctors or dentists to carry out health services can be divided into 3 (three) groups, namely:

a. Obligations arising from the nature of medical care where the doctor must act in accordance with medical professional standards or practice medicine in a lege artist manner;

b. The obligation to respect patient rights based on human rights in the health sector;

c. Obligations related to the social function of health care.

Machmud (2012) also argued that the relationship between doctors and patients was a relationship between civil law, where patients came to their doctors to cure their diseases and doctors promised to try to cure the patient's illness. Civil relations was a legal relationship carried out by parties who were in an equal position, at least when the parties would enter certain legal relations. In therapeutic transactions, there were legal subjects and legal objects. Legal subjects include patients, health workers or doctors or dentists, the legal object was maximum effort to cure the patients (Salim and Nurbani, 2014)

Therapeutic transactions that were part of the agreement between doctors and patients, which in the Civil Code were regulated in Chapter III (three) Article 1313 of the Civil Code defined an agreement was an act in which one person or more tied himself to one or more people. As part of the agreement between the doctor and the patient, it was considered valid if it fulfilled the legal requirements of the agreement set out in the 1320 Civil Code, i.e.:

a. Agree that those who bind themselves;

The firmness to have an agreement between doctors and patients in order to carry out patient health efforts was also regulated in Article 39 of the Medical Practice Law that medical practice was held based on agreement between doctors or dentists with patients in order to maintain health, prevent disease, improve health, treatment of diseases and recovery of health.

b. The ability to make an engagement;

Skills were an absolute requirement in the agreement.

c. A certain thing;

What was meant by certain things in the therapeutic agreement was an effort to cure.

d. A reason that was lawful.

Because lawful was an agreement made not in violation of laws, decency and public order. This was regulated in Article 1337 of the Civil Code that a reason was prohibited, if prohibited by law, or if it was contrary to good morality or public order.

The terms of the agreement in Article 1320 paragraph (a) and (b) of the Civil Code were subjective requirements because they related to the subject or person making the agreement, while Article 1320 paragraph (c) and (d) of the Civil Code were the objective conditions of the agreement. If the subjective conditions in the agreement were violated, the agreement can be canceled and if the objective conditions in the agreement were violated, the agreement was canceled for the sake of law.

Civil legal relations between doctors and patients which were initiated from the agreement, Nasution, B.J. (2005) explained that in the Civil Code, there were 2 (two) types of agreements, namely: 
a. Inspanning Verbintenis, that was an agreement of effort, meaning that both parties promise maximum effort to realize what was promised;

b. Resultaat Verbintenis, which was an agreement that the party promised to give a result, namely a tangible result in accordance with what was promised.

The doctor's and patient's legal relationship was included in the type of agreement of the investigator because the action of therapeutic transactions carried out by the doctor was a form of health effort in order to achieve patient recovery based on patient complaints and medical science. Doctors did not provide a guarantee of certainty in curing the disease, but with the effort and expertise of the doctor was expected to be able to assist in the effort of healing (Hariyani, 2005). This result was in line with Salim and Nurbani (2014) which stated that a therapeutic contract was equated with an inspirational agent, because in this contract the doctor was only tryingto cure the patient and the effort made was not necessarily successful.

\section{Informed Consent as Protection of Patient Rights}

Before a therapeutic transaction carried out by a doctor, it started first with the informed consent. This informed consent can provide a sense of security for the doctor when taking medical action in patients and can be used as a defense if the results of medical treatment performed by doctors were not as desired by patients and families. If the patient has given an informed consent to the doctor, then the position of the doctor became strong because in the informed consent it has been stated that if the doctor failed to carry out the obligation, the patient would not sue the doctor concerned. But judicially, the patient has the right to sue the doctor if he did not carry out professional standards properly
According to Tutik (2010), things that became consumer expectations of health care providers or patient expectations as consumers of medical services include:

a. The promised service was prompt and satisfying;

b. Helping and providing responsive services without distinguishing the elements of sara (ethnicity, religion, race and between groups);

c. Guaranteed security, safety and comfort;

d. Good communication and understanding of patient needs.

The right of the patient was actually a human right and came from individual rights (the right of self determination) and basic social rights. The two basic rights were legal principles that underlie the field of health law, namely the right to healthcare/the right to health services and the right of self-determination. In general, the right to determine his/her own destiny was regulated in the provisions of Article 28A of the 1945 Constitution which stated that:

"Everyone has the right to live and has the right to defend his life."

In Article 52, the Medical Practice Law described the patient's rights as follows:

a. Getting a complete explanation of medical actions as referred to in Article 45 paragraph (3);

b. Asking for opinions from other doctors or dentists;

c. Getting the services according to medical needs;

d. Refusing medical action; and

e. Getting the contents of medical records.

Although informed consent was an absolute right for patients but for the truth of the doctor's explanation of the patient's illness, the patient must also be cooperative and it was the duty of the patient to provide correct information about his/her health 
problems without being covered. This was regulated in Article 53 letter (a) of the Medical Practice Law which regulated patients in receiving services in medical practice having the obligation to provide complete and honest information about their health problems.

\section{Perspective of the law of informed consent in emergency situations}

The Implied Consent or Presumed Consent was the agreement given by the patient implicitly without a firm statement. The sign of this agreement was captured by the doctor from the patient's attitude and actions. Generally. the doctor's actions were ordinary actions or were well known. For example, patients came to practice and the doctor performed basic tests such as blood pressure checks and heart palpation in general, so the patient implicitly agreed with what the doctor did. This action was considered worthy of a doctor even without providing prior information.

Also in the condition of patients who need treatment or medical action immediately for example patients in an unconscious situation while in emergency situations, doctors can take immediate action even though they did not provide explanations or information to patients or their families because in this case the time was highly important.

This then raised the question to explain in more detail of the state of Emergency. The emergency department consisted of two statements namely Severe and Emergency. Severe mean there was a threat to someone's life. Whereas Emergency mean the patient needed immediate treatment. So that the meaning of the word emergency was a patient who has a health status that has a threat to his life and required immediate treatment/action.

In Article 3 paragraph (2) Chapter II of the Regulation of the Minister of Health
Number 47 of 2018 concerning Emergency Services, explained the criteria for emergencies, namely :

a. Threatening lives, endangering oneself and others / the environment;

b. There is interference with the airway, breathing, and circulation;

c. A decrease in consciousness;

d. Hemodynamic disorders; and /or

e. Requires immediate action.

Based on the case where there was an emergency patient without the identity and closest family, health personnel cannot provide help without an informed consent as a legal umbrella to conduct help or medical action. However, Article 68 paragraph 1 of Law Number 36 Year 2014 concerning Health stated that

"In principle, those who are entitled to give consent were the recipients of the health services concerned. If the recipient of health services was incompetent or under-guarded (under curatele), approval or rejection of health service measures can be given by the closest family, including husband/wife, biological father/mother, biological child, or sibling who has grown up. In an emergency, to save the lives of health care recipients, no approval was needed. However, after the Health Service Recipient was aware or in conditions that have made it possible to be immediately explained. In the case of Health Service Recipients were children or people who were unconscious, explanations were given to their families or those who take them to the hospital. If there was no one who take them to hospital and there was no family, while health care measures must be given, an explanation was given to the child or at the first opportunity when the Health Service Recipient was conscious".

In Article 4 paragraph (1) to (3) Regulation of the Minister of Health Number 290/MenKes /Per/III/2008 namely : 
1. In an emergency, to save the lives of patients and/or prevent disability approval of medical action was not required.

2. The decision to take medical action as referred to in paragraph (1) was decided by the doctor or dentist and recorded in the medical record.

3. In the event that a medical action was carried out as referred to in paragraph (1) a doctor or dentist must provide an explanation as soon as possible to the patient after the patient was conscious or to the closest family.

In terms of law and medicine, emergency services differ from non-emergency services because they have special characteristics. Some specific issues in emergency services required specific legal arrangements and would lead to different legal relationships with non-emergency conditions.

In the case of legal liability, if the patient sued health personnels because it was suspected that there was a mistake in establishing a diagnosis or therapy, the patient must prove that was only the cause of proximate causes (Holder, 1972). If the accusation of negligence was carried out in an emergency situation, it was necessary to consider the factors of the condition and situation when the event occurred. Therefore, the actions of health professionals need to be compared with qualified health personnels, in the same situation and condition (Soekanto, 1987).

Based on the results of this study, it can be concluded that:

a. Patients in emergency situations have the right to get help from a doctor without the approval of written medical measures.

b. In the case of legal liability, if there were allegations of negligence committed in an emergency situation, it was necessary to consider the conditions when the event occurred. Therefore, the actions of health personnels need to be compared with qualified health personnels with the same qualification and in the same situation and condition.

\section{REFERENCES}

Ali MM, et al. (2006). Kemitraan Dalam Hubungan Dokter-Pasien. Jakarta: Konsil Kedokteran Indonesia.

Aribowo BN, Nurhayati R, Dahlan S (2015). Persepsi pasien tentang aspek hukum perikatan upaya (Inspanning Verbintenis) dalam transaksi terapeutik antara dokter dengan pasien di RSUD Kota Salatiga. Jurnal Soepra Hukum Kesehatan. 1(1).

Ayuningtyas D, Sondani VS (2011). Informed consent communication of elective surgery patients in Karya Medika I Hospital (RSKM I) Bekasi. Journal of US-China Medical Science. 8(1).

Beauchamp TL (2001). Childress JF. Principles of Biomedical Ethics. New York: Oxford University Press.

Bertens K (2015). Etika Biomedis, Cetakan V. Yogyakarta: Kanisius.

Darmini N, Widyaningtyas RS (2014). Informed consent atas tindakan kedokteran di rumah sakit Grhasia Pakem Yogyakarta. Jurnal Mimbar Hukum. 26(2): 235.

Ghaderi A, Malek F (2014). Principles of informed consent in medicine. Koomesh, 15(2): 133-37.

Hariyani S (2005). Sengketa medik (alternatif penyelesaian perselisihan antara dokter dengan pasien). Jakarta: Diadit Media.

Isharyanto (2016). Hukum Pelayanan Kesehatan. Depok : Herya Medika.

Jendri M (2013). Hak informed consent sebagai hak pasien dalam perlindungan hak asasi manusia. Lexet Societatis. 1(4): 8. 
Kusmaryanto CB (2016). Bioetika. Jakarta: Kompas.

Machmud S (2012). Penegakan hukum dan perlindungan hukum bagi dokter yang diduga melakukan medikal malpraktek. Bandung: Karya Putra Darwati.

Majalah Kedokteran Indonesia (2007). Aspek medikolegal pelayanan gawat darurat. Jakarta: Bagian Ilmu Kedokteran Forensik dan Medikolegal Fakultas Kedokteran Universitas Indonesia/ Rumah Sakit Cipto Mangunkusumo. 57(2).

Marzuki PM (2017). Penelitian Hukum Edisi Revisi, Prenadamedia Group.

Novianto WT (2017). Hukum dalam Pelayanan Kesehatan, Cetakan 1. Surakarta: UNS Press.

Peraturan Menteri Kesehatan Nomor47 Tahun 2018 tentang Pelayanan Kegawatdaruratan

Peraturan Menteri Kesehatan No. 290 Tahun 2008 tentang Persetujuan Tindakan Kedokteran

Purbacaraka P, Soekanto S (1979). Perihal Kaedah Hukum. Bandung.

Putra S (2001). Inspanning verbintenis dan Resultaats verbintenis dalam Tran- saksi Terapetik Kaitannya dengan UU No. 8 Tahun 1999 tentang Perlindungan Konsumen. Jurnal Hukum 8(18).

Salim HS, Nurbani ES (2014). Perkembangan Hukum Kontrak Innominaat Di Indonesia (BukuKedua). Jakarta: Sinar Grafika.

Soekanto S, Herkutanto (1987). Pengantar hokum kesehatan. Jakarta: CV Remadja Karya.

Sudjito (2003). Dasar-dasar Pengelolaan Penderita Gawat Darurat. Surakarta: UNS Press.

Tutik TT (2010). Perlindungan Hukum Bagi Pasien, Jakarta: Prestasi Pustaka.

Undang-Undang No.36 Tahun 2009 tentangKesehatan

Undang-Undang No.36 Tahun 2014 tentang Tenaga Kesehatan

Undang-Undang Nomor 29 Tahun 2004 tentangPraktikKedokteran

Undang-Undang RI No. 39 tahun 1999 tentang Hak Asasi Manusia

Wiradharma D (1996). Penuntun kuliah hukum kedokteran. Jakarta: Bina Rupa Aksara. 